\title{
Floristic diversity and vegetation analysis of Wadi Arar: a typical desert Wadi of the Northern Region of Saudi Arabia
}

\author{
Ahmed K. Osman ${ }^{\text {a, b }}$, Faraj Al-Ghamdi a, c, Abdulhakim \\ Bawadekji a, d \\ ${ }^{a}$ Biology Department, College of Sciences, Northern Border University, Arar, \\ Saudi Arabia. \\ ${ }^{\mathrm{b}}$ Botany Department, Faculty of Science, South Valley University, Qena, Egypt. \\ ${ }^{\mathrm{c}}$ Botany Department, College of Sciences, King Abd El-Aziz University, Jeddah, \\ Saudi Arabia. \\ ${ }^{\mathrm{d}}$ Horticulture Department, Faculty of Agriculture, University of Aleppo, Syria.
}

Ahmed K. Osman, Faraj Al-Ghamdi, Abdulhakim Bawadekji 2014. Floristic diversity and vegetation analysis of Wadi Arar: a typical desert Wadi of the Northern Region of Saudi Arabia. Taeckholmia 34: 25-47.

\begin{abstract}
W adi Arar in the northern region of Saudi Arabia is one of the most important Wadis of the Kingdom. The present study provides an analysis of vegetation types, life forms, as well as floristic categories and species distribution. A total of 194 species representing 30 families of vascular plants were recorded. Compositae, Gramineae and Leguminosae were the most common recorded families. Therophytes and Chamaephytes are the most frequent life forms, indicating typical desert spectrum vegetation. The distribution of species in the different sectors of the Wadi as well as the phytochoria for the recorded species is provided. Eighty nine species $(45.88 \%)$ are typically bi-regional. Furthermore, about 105 species $(53.5 \%)$ are mono- and pluriregional taxa. The highest number of species (135 or $69.59 \%)$ was recorded for annual plants, while the lowest number of species (59 or $30.41 \%$ ) was recorded for perennial, short perennial or annual to biennial species.
\end{abstract}

Key words: Kingdom of Saudi Arabia; Northern region; floristic survey; flora; Wadi Arar; floristic diversity.

Received 10 July 2014, Accepted 10 Aug. 2014 


\section{Introduction}

The Kingdom of Saudi Arabia is a huge arid land with an area of about $2,250,000 \mathrm{~km}^{2}$ covering the major part of the Arabian Peninsula, characterized by different ecosystems and diversity of plant species (Abdel Khalik et al., 2013).

The topography of Saudi Arabia, as well as that of the Arabian Peninsula, is an ancient massif in which geologic structure developed concurrently with the Alps (Country Profile: Saudi Arabia, 2006). The climate in Saudi Arabia differs greatly between the coast and the interior. High humidity coupled with more moderate temperatures is prevalent along the coast, whereas aridity and extreme temperatures characterize the interior (Country Profile: Saudi Arabia, 2006).

The word "Wadi" in this article will be used to designate a temporary river, which its runoff is dependent to rain. In the dry lands, Wadis represent one of the most prominent desert landforms, which exhibit physiographies irregularities that lead to parallel variations in distribution of plant species (Kassas and Girgis, 1964). Wadi "Arar" is considered one of the most important wadis in the northern region.

The flora of Saudi Arabia is one of the richest biodiversity in the Arabian Peninsula and comprises very important genetic resources of crops and medicinal plants (Atiqur Rahman, et al., 2004). The components of this flora are an admixture of Asia, Africa and Mediterranean region's plants. According to Collenete (1999), this flora comprises 2,250 species belonging to 835 genera and about 142 families: 147 species are "endemic", 721 species are "endangered" and about 22 species are nearly extinct.

The number of wild species occurring in a square kilometer area of Saudi Arabia is less significant, especially in areas such as central, eastern and northern regions. Areas along the northwestern and southwestern regions are densely vegetated and contain the highest number of species. Approximately $70 \%$ of the country's species are reported in these areas. Endemism in Saudi Arabia is relatively insignificant in comparison with some of the neighboring countries such as Yemen and Oman (http://plantdiversityofsaudiarabia.info/index.htm).

Wild plants of Saudi Arabia were studied by many authors (Chaudhary, 1999-2001; Chaudhary and Al Jowaid, 1999; Collenette, 1999; Migahid, 1996; Miller and Cope, 1996) as general floral studies. Furthermore, many authors have studied more limited areas in the course of floral and 
taxonomical revision of some genera (Aleem, 1979; Batanouny and Ismail, 1985; Fayed and Zayed, 1989; El Karemy and Zayed, 1992; Hajar et al., 1998; Hegazy et al., 1998; Al Wadie, 2002; AI-Turki and AI-Olayan, 2003; Atiqur Rahman et al., 2004; Alfarhan et al., 2005; Mosallam, 2007; Alshammari and Sharawy, 2010; El-Ghanim et al., 2010; Al-Sodany et al., 2011; Alatar et al., 2012; Alsherif et al., 2012; Farrag, 2012; Gomaa, 2012; Ihsanullah Daur, 2012; Waly et al., 2012 and Abdel Khalik et al., 2013).

The distribution of life form is closely related to topography and landform (Kassas and Girgis, 1965; Zohary, 1973; Orshan, 1986; Fakhireh et al., 2012). In Wadis, the composition of life forms expresses a typical desert flora, the majority of species being therophytes and chamaephytes. Vegetation of wadis in general is not constant; it varies from year to year, depending upon the moisture level (Siddiqui and Al-Harbi, 1995). The establishment, growth, regeneration and distribution of the plant communities in the wadis are controlled by many factors, such as geographical position, physiographies features and human impacts (Shaltout and El-Sheikh, 2003; Kürschner and Neef, 2011; Alatar et al., 2012 and Korkmaz and Ozcelik, 2013).

The current study aims to surveying and identification of the wild plant species growing in Wadi Arar and the surrounding areas in the northern region of Saudi Arabia. Moreover, the vegetation types, life forms and floristic categories of the collected species were taken into consideration. For the future reference, voucher herbarium specimens of different plant samples were deposited in the herbarium of the College of Sciences in Arar (Northern Border University).

\section{The Study Area}

The area of the present study is located in the Northern region of Saudi Arabia ( $30^{\circ} 55^{\prime} 13^{\prime \prime} \mathrm{N}, 41^{\circ} 0^{\prime} 3^{\prime \prime} \mathrm{E}$ ). Wadi Arar (Wadi of the Anizah tribe) is one of the main Wadis which existed in the northeast of Saudi Arabia (Figure 1). It covers an area of about $9500 \mathrm{~km}$ square and extends next to Arar city (Map 1). According to the Worldwide Bioclimatic Classification System (http://www.globalbioclimatics.org), this region falls within the Mediterranean desert continental climate. This area is dry zone, characterized by hot, arid, desert climate and an average annual temperature of $21.5^{\circ} \mathrm{C}$ (Figure 2). Precipitation is scanty, with an average annual of 20.2 $\mathrm{mm}$, which usually falls during the winter months, the extreme rainfall 
occurring in January and May with more than $90 \mathrm{~mm}$ (http://www. globalbioclimatics.org).

\section{Material and methods}

This study was performed in Wadi Arar from November 2011 to April 2013 during active plant growth period, when most species were expected to be present. The wild vegetation was sampled in 25 localities including the different Wadi tributaries.

The collected plant specimens were identified according to Collenette (1999), Cope (1985), Megahid (1996), and Chaudhary (1999-2001); and deposited in the Herbarium of Biology Department, College of Sciences, Northern Border University.

Life forms of the traced species were determined according to Raunkier (1934). The floristic categories of the investigated species were made according to Wickens (1978) and Zohary (1973).

\section{Results}

Table (1) showed the plant species recorded in the different surveyed sectors of Wadi Arar. The list includes 194 species belonging to 30 families of phanerogams. Their generic representation is quite variable. Compositae, Gramineae and Cruciferae were represented with the highest number of genera as 29, 19 and 14; respectively. Five families are represented by four to eight genera (Caryophyllaceae and Leguminosae with 8 genera; Umbelliferae with 7 genera and Zygophyllaceae with 4 genera). Furthermore, eight families were represented by 2 or 3 genera and 14 families are represented by a single genus (Table 1).

From the standpoint of species richness within the described families of the region, only one family exceeded 30 species (Compositae: 48), one family was represented by 26 species (Gramineae), the third family contained 22 species (Leguminosae), two families had more than 10 species (Caryophyllaceae: 12 and Cruciferae: 17). Moreover, seven families showed eight to five species (Boraginaceae: 5, Labiatae and Zygophyllaceae: 6 each, Plantaginaceae: 7, Umbelliferae and Chenopodiaceae: 8 genera each, 2 families were represented by three species, five possessed two species only and 11 families were represented by a single species as shown in Table (1).

With regard to the growth type, the majority of the recorded species in the present study were annual plants 135 species (69.59\%) of the total 
recorded species. The second most recorded growth types were the perennials, which were represented by 52 species $(26.80 \%)$ of the total species. The remaining growth types (biennial, annual or short-perennial and annual or biennial) in the investigated area not exceeding two species and ultimately only one species was recorded as a short-perennial (Launaea mucronata sp. mucronata Table 2 and Figure 3 ).

Table (2) showed the life form spectra of the recorded species according to the classification of Raunkiaer (1937). Therophytes were the most frequent life form represented by 139 species, followed by chamaephytes with 33 species and hemicryptophytes with 16 species, with a percentage of $71.65 \%, 17.01 \%$ and $8.24 \%$ of the total recorded species respectively. Two species were geophytes (Cynodon dactylon and Polypogon maritimus) and both cryptophytes and phanerophytes were represented only by a single species (Reichardia tingitana and Calotropis procera; respectively). Parasitic species were represented by two species from two different families (Cuscuta campestris and Cistanche phelypaea; Table (2) and Figure 4).

From a phytogeographical point of view, the recorded species in the different sectors of Wadi Arar may be classified as monoregional, biregional or pluriregional taxa. A total of 46 species representing $23.71 \%$ of the total number of recorded species were monoregional taxa of different affinities. The recorded monoregional species fall under three main phytochoria: Irano-Turanian taxa (15 species forming $7.73 \%$ of recorded species), Saharo-Sindian taxa (13 species forming $6.70 \%$ of recorded species) and Saharo-Arabian taxa (10 species forming $5.16 \%$ of recorded species). Among these, six species were typical Mediterranean species (Atractylis carduus, Helichrysum conglobatum, Astragulus schemperenniali, Hippocrepis cyclocarpa, Plantago crassifolia and Ammi majus). Mediterranean species were rarely represented in the different sectors of the Wadi. The phytochoria Sudano-Zambezian was rarely represented in the different sectors of the Wadi with only two species (Haloxylon salicornicum and Eragrostis aegyptiaca) forming $1.03 \%$ of the total number of recorded species (Table 3, Figures 5, 6).

The other 89 species $(45.88 \%)$ were biregional taxa. Both the two phytochorial regions Mediterranean-Saharo-Sindian and MediterraneanIrano-Turanian were represented by 19 species (9.79\%). Saharo-SindianIrano-Turanian region was represented by 17 species $(8.77 \%)$. SaharoSindian-Sudano-Zambezian region was represented by 16 species $(8.25 \%)$. 
Both Mediterranean-Saharo-Arabian and Saharo-Arabian-Irano-Turanian two regions were represented by eight species (4.12\%) and six species (3.09\%); respectively. Irano-Turanian-Euro-Siberian region was represented by two species (Artemisia scoparia and Centaurea sinaica). Only one species was recorded in both Saharo-Arabian-Sudano-Zambezian region (Calotropis procera) and Mediterranean-Sudano-Zambezian region (Hippocrepis areolata; Table (3) and Figures $5 \& 6$ ).

Thirty nine species representing $20.10 \%$ of the recorded species were pluriregional taxa of different affinities. The recorded pluriregional species represented in three main phytochoria: Mediterranean-Saharo-SindianIrano-Turanian phytochorion (14 species forming $7.20 \%$ of recorded species) and both Mediterranean-Saharo-Arabian-Irano-Turanian and Mediterranean-Irano-Turanian-Euro-Siberian two phytochoria (six species for each phytochorion forming 3.09\% of recorded species). MediterraneanIrano-Turanian-Sudano-Zambezian, Mediterranean-Saharo-Sindian-IranoTuranian-Euro-Siberian, Mediterranean-Saharo-Sindian-Irano-TuranianSudano-Zambezian and SaharoArabian-Irano-Turanian-Sudanian regions were represented by two species (1.03\%) which were Lamarckia aurea, Setaria pumila; Sisymbrium irio, Zilla spinosa; Citrullus colocynthis, Cistanche phelypaea and Stipagrostis ciliata, Triticum aestivum; respectively. Only one species $(0.52 \%$ of the recorded species) occurred in the following regions: Mediterranean-SaharoArabian-Irano-Turanian-EuroSiberian (Eruca sativa), Mediterranean-SaharoArabian-Irano-TuranianSudanian (Alhagi graecorum), Mediterranean-SaharoArabian-SudanoZambezian (Oligomeris linifolia), Mediterranean-Saharo-Sindian-SudanoZambezian (Rumex vesicarius) and Saharo-Sindian-Irano-Turanian-SudanoZambezian (Launaea nudicaulis). The remaining twenty species were distributed as follows: 12 species are Cosmopolitan, followed by four Palaeotropical species and four Pantropical species (Table (3) and Figures 5 \& 6). 


\section{Discussion and conclusions}

In the present study, which focused on the flora of the Wadi Arar area, five of recorded families (Compositae, Gramineae, Leguminosae, Caryophyllaceae and Cruciferae) represent nearly two thirds of the total flora. The most representative families of this region were corresponded to a typical Mediterranean-North African floristic structure and this agrees with the results of study carried out by Quézel (1978).

According to Al-Hassan (2006), about 458 species which belong to these floristic structures were represented in the northern sector of the Kingdom of Saudi Arabia. In Wadi Arar area, the present survey recorded 194 species, and this represented over one third of the checklist recorded before in the whole northern region of the Kingdom. The total number of recorded genera was 129, indicating a high generic index of 1.5 (194/129). These results were conforming to those of Pielou (1975) and Magurran (1988), where the taxonomic diversity is higher in an area in which the species were belonging to many genera. Species diversity in Wadi Arar is 1.5 for species/genera ratio and 6.3 for genera/families. This indicates higher species diversity in the studied region than in other areas (Tables $1 \& 2$ ). This high diversity was due to the abundance of water sources, soil fertility and the diversity of relief (open shallow valleys, mountains and sand dunes) as mentioned by Al-Shammari (2010) and Al-Shammari and Sharawy (2010).

The natural vegetation in the study area comprised 194 plant species, including 135 annuals $(69.59 \%)$ and 52 perennials (26.80\%). The highest contribution of annuals can be attributed to their short life cycle that enables them to resist the instability of the ecosystem (Gomaa, 2012). Moreover, they were generally characterized by a high allocation of resources to the reproductive organs (Harper, 1977) and the production of flowers early in their lifespan to ensure some seed production even in a year when the growing season is cut short (Sans and Masalles, 1995). These results corroborated previous studies focusing on a Hail province (AI-Turki and AI-Olayan, 2003; Sharawy and Al-Shammari, 2009 and Al-Shammari and Sharawy, 2010).

The vegetation of northern region has no appreciable contribution to the flora of Saudi Arabia with regard to other parts of the country (AI-Turki and AI-Olayan 2003). It is also dominated by annual species. The studied area was widely regarded as a transition zone between the floristic regions of the Mediterranean, Irano-Turanian and Saharo-Sindian, Saharo-Arabian or 
Sudano-Zambezian regions. The influences of these phytogeographical zones were very much reflected in the flora of the Northern region. The other floristic elements such as cosmopolitan, pantropical, palaeotropical, Euro-Siberian and Sudanian elements were represented by a variable number of species reflecting their differential capability to penetrate the region (AI-Turki and AI-Olayan 2003).

Among the recorded species from this region, some were extremely rare and poorly known and their results reveal that some of these plants had been collected from a single locality (Calotropis procera, Gypsophila sp. and Cistanche phelypaea), while others have been collected in the studied area only once or twice (Aerva javonica, Anthemis sp., Koelpinia linearis, Solanum nigrum and Anagallis arvensis), this results supported by the earlier one on the same area carried out by AI-Turki and AI-Olayan (2003).

Regarding the life forms spectra, therophytes had the highest contribution, followed by chamaephytes, hemicryptophytes, parasites, geophytes and finally both phanerophytes and cryptophytes (Tables 1, 2 and Figure 4). The life form of desert plants is closely linked with rainfall, topography and land form (Kassas and Girgis, 1965; Zohary, 1973; Orshan, 1986). Therophytes (which had a lifespan as short as few weeks) as Amaranthus viridis, Cleome amblyocarpa, Calendula arvensis species recorded in this area, are characteristic of desert regions (Gomaa, 2012).

Considering the florists categories in the study area, the results indicate that Irano-Turanian elements predominate the studied area (97 species, $49.5 \%$ ), and were represented as mono-regional (15 species, $7.73 \%$ ), biregional under the influence of Mediterranean, Saharo-Arabian, EuroSiberian and Saharo-Sindian regions (44 species, 22.68\%) and Pleuriregionals under the influence of Mediterranean, Saharo-Sindian, SaharoArabian, Euro-Siberian, Sudano-Zambezian and Sudanian regions (37 species, $19.07 \%$ ). Mediterranean region was represented by 89 species (or $45.88 \%$ ), followed by Saharo-Sindian region (85 species, 43.81\%), followed by Sudano-Zambezian region (45 species, 23.20\%) and at last SaharoArabian region (36 species, 18.56\%). Taxa of wide geographical range, like Cosmopolitan (12 species, 6.18\%), Palaeotropical (4 species, $2.06 \%$ ) and Pantropical (4 species, $2.06 \%$ ), has apparently lower presence value (Table 3 ). 


\section{Acknowledgment}

The authors are grateful to Deanship of Scientific Research, Northern Border University, for supporting this research. They are thanked also Dr. Arabi M. Guetat, Biology Department, College of Science, and Northern Border University for great help throughout the present study.

\section{References}

Abdel Khalik, K., El-Sheikh, M., El-Aidarous, A., 2013. "Floristic diversity and vegetation analysis of Wadi Al-Noman, Holy Mecca, Saudi Arabia". Turk. Jour. Bot. 37: 894-907.

Alatar, A., El-Sheikh, M.A., Thomas, J., 2012. "Vegetation analysis of Wadi Al-Jufair, a hyper-arid region in Najd, Saudi Arabia". Saudi Jour. Biol. Sci. 19: 357-368.

Aleem, A.A., 1979. A contribution to the study of sea grasses along the Red Sea coast of Saudi Arabia. Aquatic Bot. 7: 71-78.

Alfarhan, A.H., Al-Turki, T.A., Basahy, A.Y., 2005. Flora of Jizan Region. Vol.1, King Abdulaziz City for Science and Technology (KACST).

Al-Hassan, H.O., 2006. Wild plants of Northern Region of the Kingdom of Saudi Arabia (Field guide with photography). Ministry of Agriculture, Camel and Range Research Center, Al-Jouf, Saudi Arabia.

Al-Shammeri, M.A., 2010. Historical Hema Faid. Hail University, Hail, Saudia Arabia.

Al-Shammari, A.M., Sharawy, S.M., 2010. Wild plants diversity of the Hema Faid Region (Hail Province, Saudi Arabia). Asian Jour. Pl. Sci. 9(8): 447-454.

Alsherif, E.A., Ayesh, A.M., Allogmani, A.S., Rawi, S.M., 2012. Exploration of wild plants wealth with economic importance tolerant to difficult conditions in Khulais Governorate, Saudi Arabia. Scientific Research and Essays, 7(45): 3903 -3913.

Al-Sodany, Y.M., Mosallam, H.A., Bazaid, S.A., 2011. Vegetation analysis of Mahazat Al-Sayd Protected Area: The second Largest Fenced Nature Reserve in the World. World Appl. Sci. Jour. 15 (8): 1144-1156. 
Al-Turki, T.A., Al-Qlayan, H.A., 2003. Contribution to the flora of Saudi Arabia: Hail region. Saudi Jour. . Biol. Sci. 10: 190-222.

Al Wadie, H., 2002. Floristic composition and vegetation of Wadi Talha, Asser Mountains, South West Saudi Arabia. Journal of biological Sciences, 2: 285-288.

Atiqur Rahman, M., Mossa, J.S., Al-Said, M.S., Al-Yahya, M.A., 2004. Medicinal plant diversity in the flora of Saudi Arabia 1: a report on seven plant families. Fitoterapia, 75: 149-161.

Batanouny, K., Ismail, A., 1985. Plant communities along Medina-Badr road across the Hejaz Mountains, Saudi Arabia. Vegetatio 53: 3343.

Chaudhary, S.A., 1999-2001. Flora of the Kingdom of the Saudi Arabia, vols. 1-3, Riyadh: Ministry of Agriculture and Water press.

Chaudhary, S.A., Al-Jowaid, A.A., 1999. Vegetation of the Kingdom of Saudi Arabia. National Agriculture and Water Research Center. Ministry of Agriculture and Water. Riyadh, Saudi Arabia.

Collenette, S., 1999. Wild Flowers of Saudi Arabia, Riyadh: National Commission for Wild Life Conservation and Development (VCWCD.

Cope, T., 1985. A key to the grasses of Arabian Peninsula. Arabian Journal Science Research, Special Publication.

Country Profile: Saudi Arabia, September (2006) Library of Congress Federal research division (http://lcweb2.loc.gov/frd/cs/profiles/Saudi_Arabia.pdf).

El-Ghanem, W.A., Hassan, L.M., Galal, T.M., Badr, A., 2010. Floristic composition and vegetation analysis in Hail region north of central Saudi Arabia. Saudi Jour. .Biol. Sci. 17: 119-128.

El Karemy, Z., Zayed, K., 1992. Distribution of Plant Communities across Al Abna Escarpment, SW Saudi Arabia. Phyton 32: 79-101.

Fakhireh, A., Ajorlo, M., Shahryari, A., Mansouri, S., Nouri, S., Pahlavanravi, A., 2012. The autecological characteristics of Desmostachya bipinnata in hyper-arid regions. Turk. Jour. Bot. 36: 690-696.

Farrag, H.F., 2012. Floristic composition and vegetation-soil relationships in Wadi Al-Argy of Taif region, Saudi Arabia. Inter. Res. Jour. . Pl. Sci.3(8): 147-157.

Fayed, A., Zayed, K., 1989. Vegetation along Makkah-Taif road (Saudi Arabia). Arab. Gulf Jour. .Sci. Res. 7: 97-117. 
Gomaa, N. H., 2012. Composition and diversity of weed communities in Al-Jouf province, northern Saudi Arabia. Saud. Jour. Biol. Sc. 19: 369-376.

Hajar, A., Yousef, M., Baeshin, N., 1998. Studies on the plant ecology and phytosociology of Al-Bahah region, Saudi Arabia: 1. Area along AlBahah - Al-Qonfodah road. Bull. Fac. Sci. Assuit Univer. 27: 53-84.

Harper, J.L., 1977. Population Biology of Plants. London : Academic Press.

Hegazy, A.K., El-Demerdash, M.A., Hosni, H.A., 1998. Vegetation, species diversity and floristic relations along an altitudinal gradient in south-west Saudi Arabia. Jour. Arid Envir. 38: 3-13.

Ihsanullah, Daur., 2012. Plant flora in the rangeland of western Saudi Arabia. Pak. Jour. Bot. 44: 23-26.

Kassas, M., Girgis, W.A., 1964. Habitat and plant communities in the Egyptian desert. V. The limestone plateau. Jour. Ecol. 52: 107-119.

Kassas, M., Girgis, W.A., 1965. Habitat and plant communities in the Egyptian desert. VI. The units of a desert ecosystem. Jour. Ecol. 53: 715-728.

Korkmaz, M., Ozcelik, H., 2013. Soil-plant relations in the annual Gypsophila (Caryophyllaceae) taxa of Turkey. Turk. Jour. Bot. 37: 85-98.

Kürschner, H., Neef, R., 2011. A first synthesis of the flora and vegetation of the Tayma oasis and surroundings (Saudi Arabia). Pl. Diver. Evol. 129: $27-58$.

Magurran, A.E., 1988. Ecological diversity and it $s$ Measurement Princeton. Princeton University Press, Pinceton, New Jersy.

Migahid, A.M., 1996. Flora of Saudi Arabia, vols. 2. Jeddah: King Abdul Aziz University Press.

Miller, A.G., Cope, T.A., 1996. Flora of Arabian Peninsula and Socatra. Edinburgh University press in association with Royal Botanical Gardens Edinburgh and Royal Botanical Gardens Kew. England.

Mosallam, H.A., 2007. Comparative study on the vegetation of protected and non-protected areas, Sudera, Taif, Sauidi Arabia. Intern. Jour..agricul. . Biol. 9: 202-214.

Orshan, G., 1986. The desert of the Middle East. In: Evenari M, Noy-Meir I and Goodall DW (eds.), Ecosystems of the World, 12 B, Hot Deserts and Arid Shrublands. Amsterdam: Elsevier. 
Pielou, E.C., 1975. Ecological diversity. $1^{\text {st }}$ ed., Wiley Interscience, New York.

Quézel, P., 1978. Analysis of the flora of Mediterranean and Saharan Africa. Ann. Miss. Bot. Gard. 65: 479-534.

Raunkiaer, C., 1934. Life forms of plants and statistical plant geography. Oxford: The Clarendon Press.

Sans, F.X., Masalles, R.M., 1995. Phenological patterns in an arable land weed community related to disturbance. Weed Res. 35: 321-332.

Shaltout, K.H., El-Sheikh, M.A., 2003. Vegetation of the urban habitats in the Nile Delta region, Egypt. Urban Ecosystems 6: 205-221.

Sharawy, S.M., Alshammari, A.M., 2009. Checklist of poisonous plants and animals in Aja Mountain, Hail region, Saudi Arabia, Aust. J. Basic Appl. Sci. 3: 2217-2225.

Siddiqui, A.Q., Al-Harbi, A.H., 1995. A preliminary study of the ecology of Wadi Hanifah stream with reference to animal communities. Arab Gulf Jour. Sci. Res.13: 695-717.

Waly, N.M., Al-Zahrani, H.S., Felemban, W.F., 2012. Taxonomical Studies of Some Acacia Seeds Growing in Saudi Arabia. Jour. . Amer.Sci. 8(3): 264-275.

Wickens, G.E., 1978. The flora of Jebel Marra (Sudan Republic) and its geographical affinities. Kew Bull. Add.Ser. :5-385.

Zohary, M., 1973. Geobotanical foundations of the Middle East. Stuttgart: Gustav Fischer -Verlag.

Electronic references

http://www.plantdiversityofsaudiarabia

http://www.globalbioclimatics.org

http://en.wikipedia.org/wiki/List_of_cities_and_towns_in_Saudi_Arabia

http://sa.geoview.info/sha_ib_ushbah,408372 


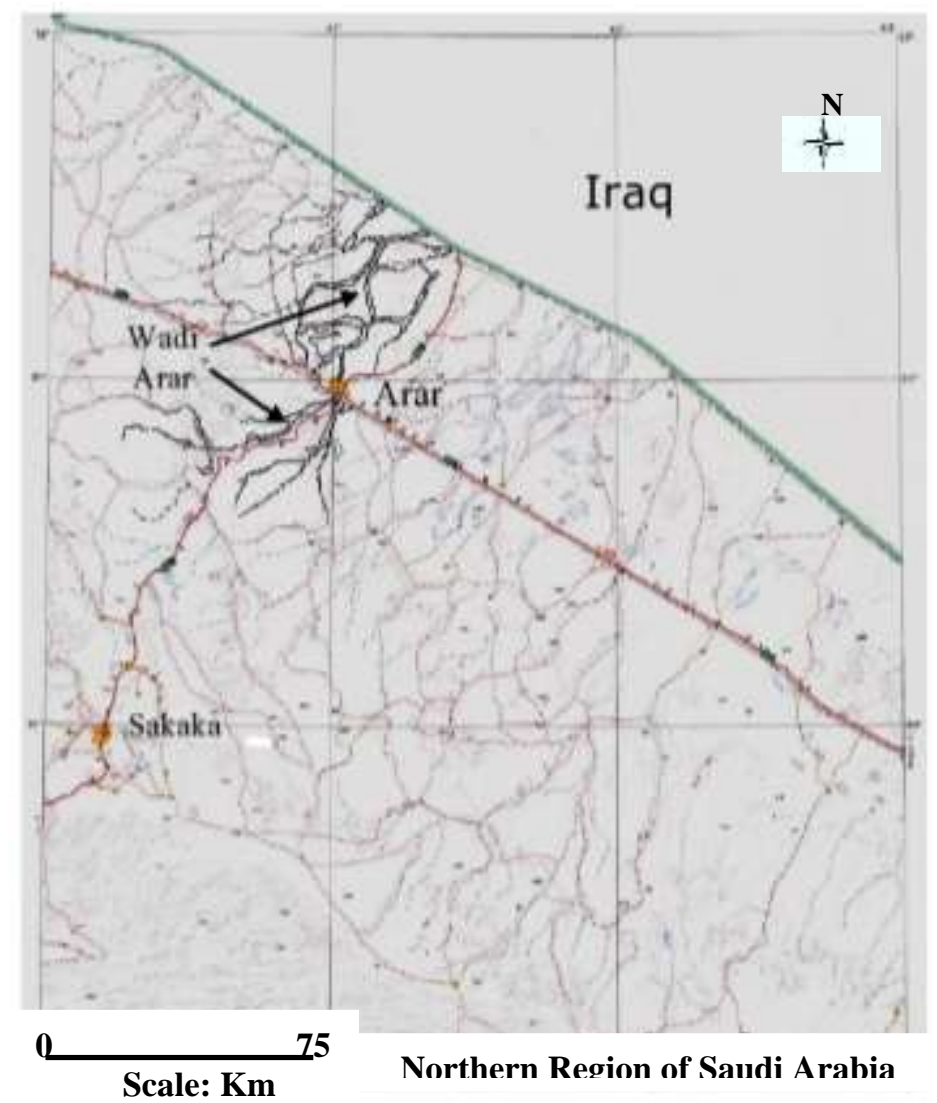

Figure 1. Location map of Saudi Arabia showing the Northern Region. 


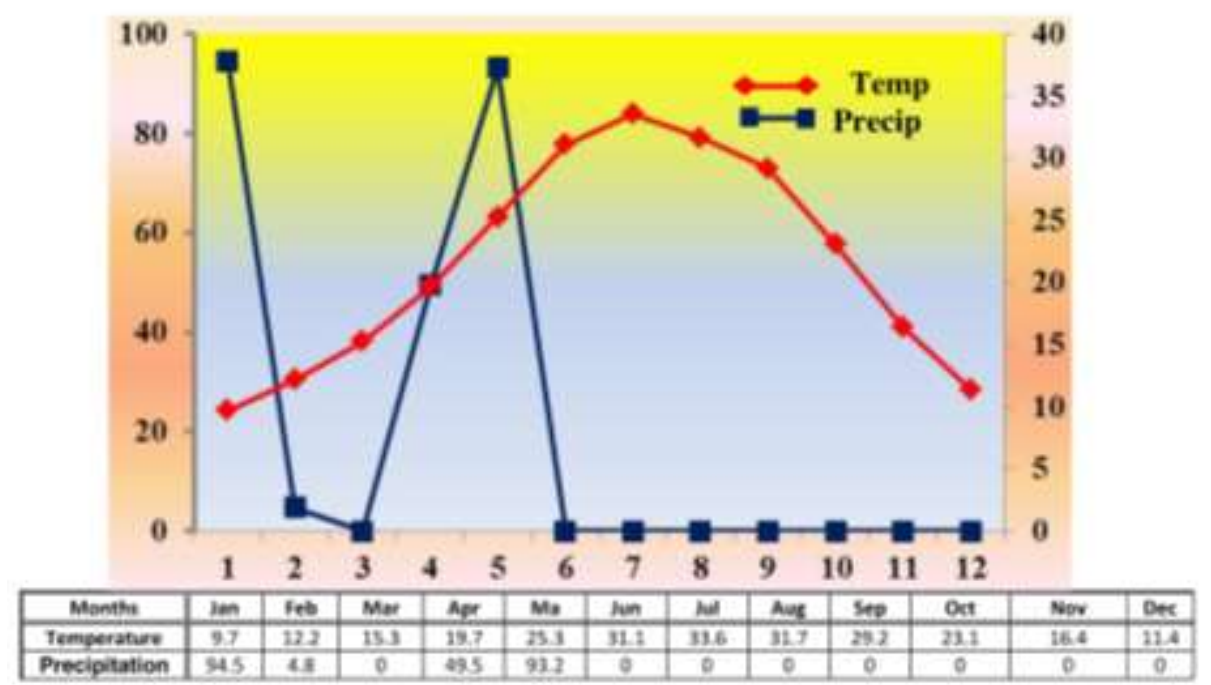

Figure 2. Climate diagram for Arar, Northem Border Repion, Saudi Arabia.

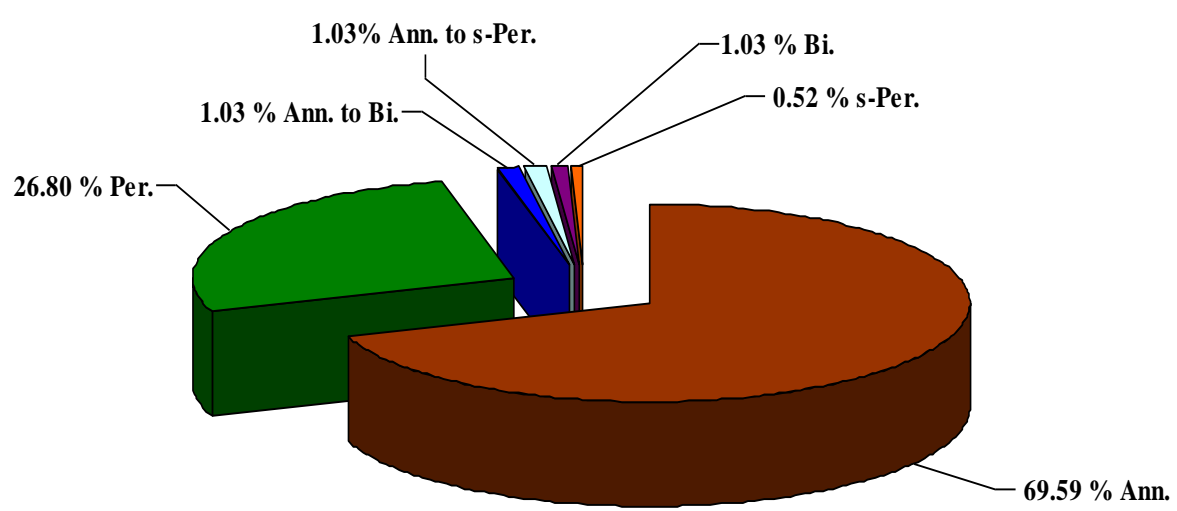

Figure 3. Vegetation type relative spectrum of Wadi Arar vegetation: A. = annual; Bi. = Biennial; P. = Perennial; s-P. = short Perennial. 


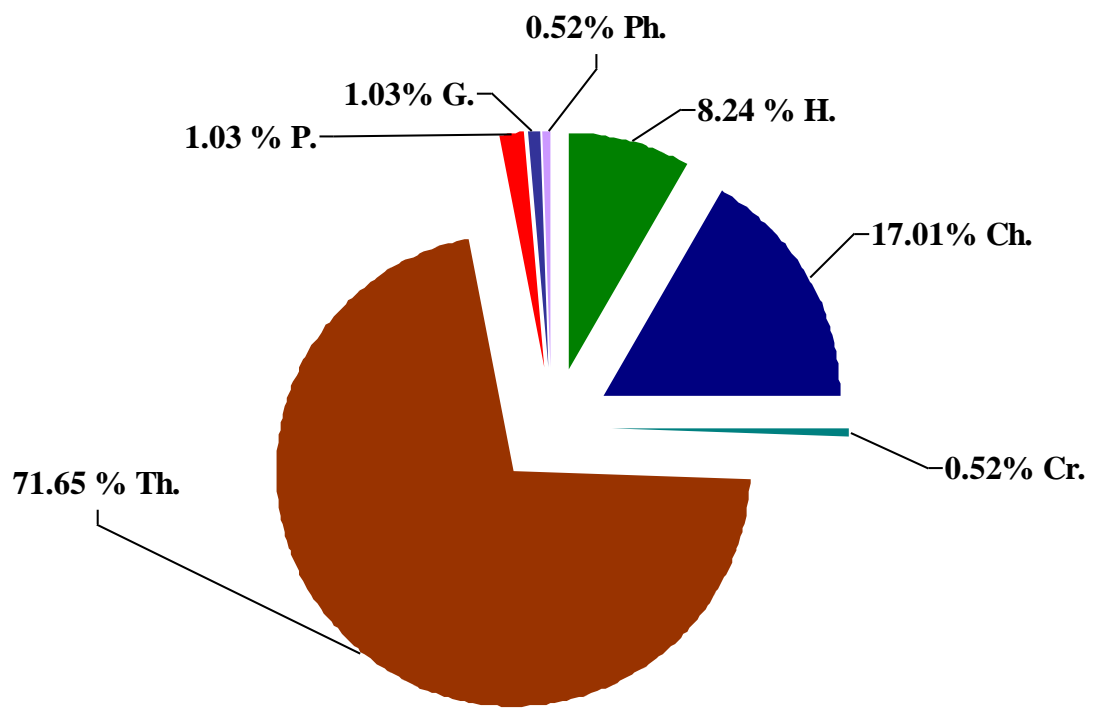

Figure 4. Life form relative spectrum of Northern region vegetation of Saudi Arabia. Th. $=$ Therophyte, Ph. $=$ Phanerophyte, H. $=$ Hemicryptophyte, $\mathrm{P} .=$ Parasite and G. = Geophyte.

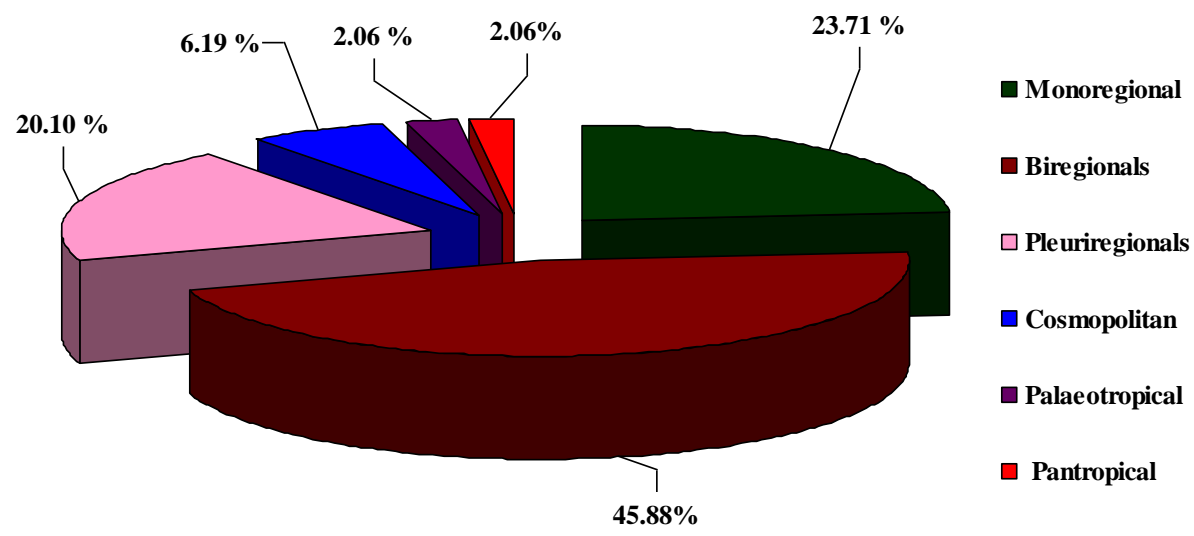

Figure 5. Floristic category spectrum of Wadi Arar according to number of vegetation regions. 


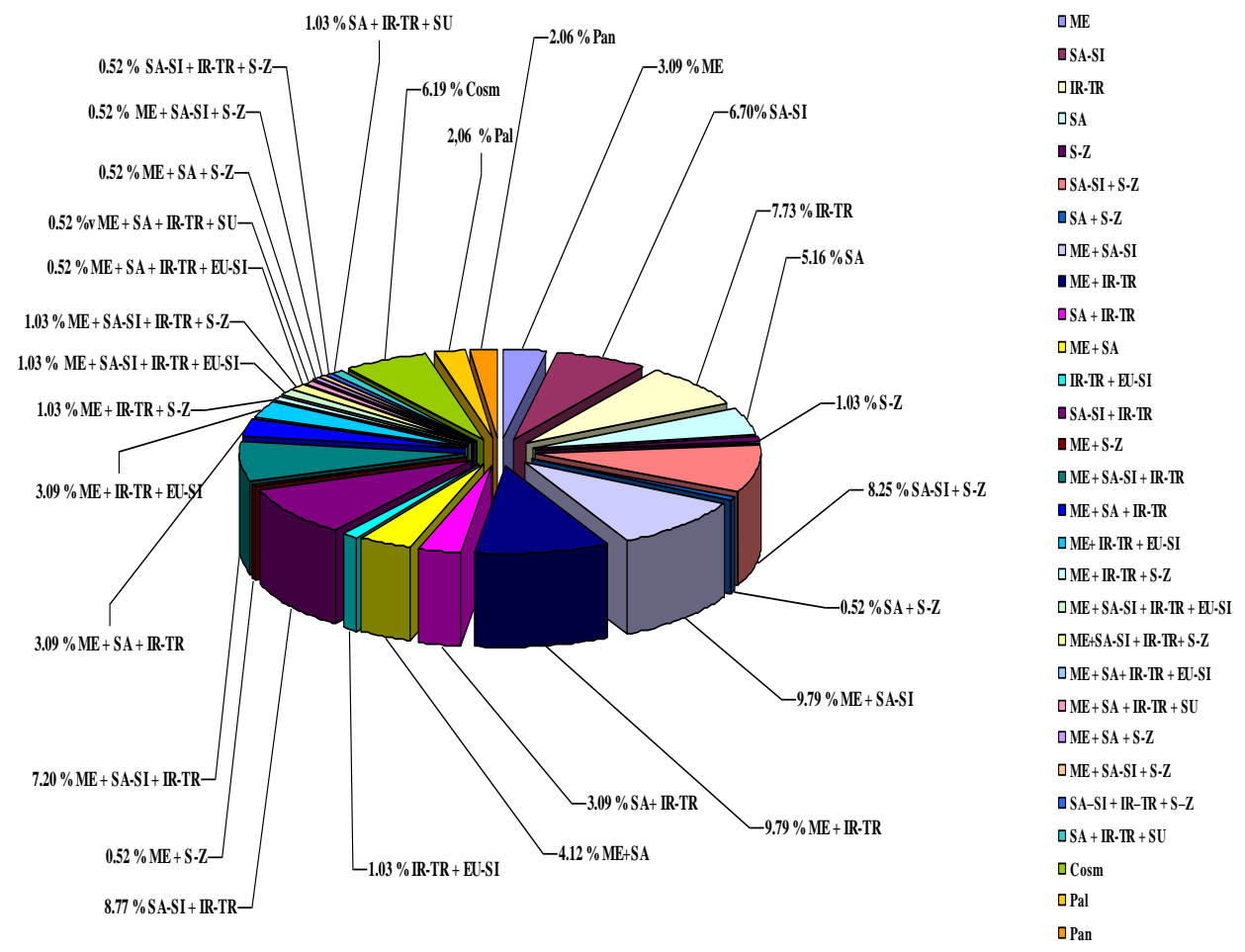

Figure 6. Floristic category spectrum of the Northern region of Saudi Arabia: COSM = Cosmopolitan; EU-SI = Euro-Siberian; IR-TR = Irano-Turanian; $\mathrm{ME}=$ Mediterranean; PAL = Palaeotropical; PAN = Pantropical; S-Z = SudanoZambezian; SA = SaharoArabian; SA-SI = Saharo-Sindian; SU = Sudanian; TR $=$ Tropical. 
Table (1). List of recorded species in the study area with their families, vegetation type, life form and floristic categories.

- Vegetation type (V. t.): A. = annual; Bi. = Biennial; P. = Perennial; s-P. $=$ short Perennial.

- $\quad$ Life form (L. f.): $\mathbf{C h}=$ Chamaephytes; $\mathbf{C r}=$ Cryptophytes; $\mathbf{G}=$ Geophytes; $\mathbf{H}=$ Hemicryptophytes; $\mathbf{P}=$ Parasites; $\mathbf{P h}=$ Phanerophytes; $\mathbf{T h}=$ Therophytes.

- $\quad$ Floristic categories (the Chorotypes): COSM = Cosmopolitan; EU-SI = EuroSiberian; IR-TR = Irano-Turanian; ME = Mediterranean; PAL = Palaeotropical; PAN = Pantropical; S-Z = Sudano-Zambezian; SA = SaharoArabian; SA-SI = Saharo-Sindian; $\mathbf{S U}=$ Sudanian; $\mathbf{T R}=$ Tropical.

\begin{tabular}{|c|c|c|c|c|}
\hline Family & Species & V.t. & L. f. & Floristic Categories \\
\hline Aizoaceae & Aizoon canariense $\mathrm{L}$. & P. & $\mathbf{H}$ & SA-SI + S-Z \\
\hline \multirow[t]{3}{*}{ Amaranthaceae } & Aerva javonica (Burm. f.) Juss. ex Scult. & P. & Ch & SA-SI + S-Z \\
\hline & Amaranthus graecizans $\mathbf{L}$. & A. & Th & PAL \\
\hline & Amaranthus viridis $\mathrm{L}$. & A. & Th & COSM \\
\hline \multirow[t]{2}{*}{ Asclepiadaceae } & Calotropis procera (Aiton) W. T. Aiton & P. & $\mathbf{P h}$ & $\mathbf{S A}+\mathbf{S}-\mathbf{Z}$ \\
\hline & Pergularia tomentosa $\mathrm{L}$. & P. & $\mathbf{C h}$ & SA-SI + S-Z \\
\hline \multirow[t]{4}{*}{ Boraginaceae } & $\begin{array}{l}\text { Arnebia decumbens (Vent.) Coss. \& Kralik var. } \\
\text { decumbens }\end{array}$ & A. & Th & SA-SI + S-Z \\
\hline & $\begin{array}{l}\text { Arnebia decumbens (Vent.) Coss. \& Kralik var. } \\
\text { macrocalyx Coss. \& Kralik }\end{array}$ & A. & Th & $\mathbf{S A - S I}+\mathbf{S}-\mathbf{Z}$ \\
\hline & Arnebia linearifolia A. DC. & A. & Th & SA-SI + S-Z \\
\hline & 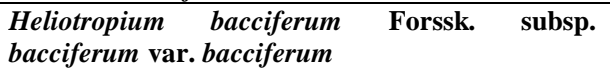 & $\mathbf{P .}$ & Ch & SA-SI + S-Z \\
\hline \multirow[t]{12}{*}{ Caryophyllaceae } & Gypsophila capillaris (Forssk.) C. Chr. & A. & Th & SA \\
\hline & $\begin{array}{l}\text { Gypsophila linearifolia (Fisch. \& C. A. Mey.) } \\
\text { Boiss. }\end{array}$ & A. & Th & IR-TR \\
\hline & Gypsophila viscosa Murray & A. & Th & IR-TR \\
\hline & Herniaria hemistemon J. Gay & P. & Th & ME + SA-SI \\
\hline & Herniaria hirsuta $\mathrm{L}$. & A. & Th & ME + SA-SI \\
\hline & Paronychia arabica $($ L.) DC. & A. & Th & ME + SA-SI + IR-TR \\
\hline & $\begin{array}{l}\begin{array}{l}\text { Polycarpaea robbairea } \\
\text { Burdet }\end{array} \\
\text { (Kuntze) Greuter \& }\end{array}$ & $\mathbf{P}$. & $\mathbf{H}$ & SA-SI + S-Z \\
\hline & Polycarpon tetraphyllum (L.) L. & A. & Th & ME + SA-SI + IR-TR \\
\hline & Pteranthus dichotomus Forssk. & A. & Th & ME + SA + IR-TR \\
\hline & Silene arabica Boiss. & A. & Th & SA-SI \\
\hline & Spergularia diandra (Guss.) Boiss. & A. & Th & ME + SA + IR-TR \\
\hline & Spergularia marina (L.) Griseb. & A. & Th & ME + IR-TR \\
\hline \multirow[t]{8}{*}{ Chenopodiaceae } & $\begin{array}{l}\text { Atriplex leucoclada Boiss. var. turcomanica } \\
\text { (Moq.) Zohary. }\end{array}$ & $\mathbf{P .}$ & Ch & ME + SA-SI \\
\hline & Bassia eriophora (Schrad.) Asch. & A. & Th & SA + IR-TR \\
\hline & Chenopodium ambrosioides $\mathbf{L}$. & Bi. & Th & COSM \\
\hline & Chenopodium murale $\mathrm{L}$. & A. & Th & COSM \\
\hline & Haloxylon salicornicum (Moq.) Bunge ex Boiss. & P. & Ch & $\mathbf{S - Z}$ \\
\hline & Salsola villosa Delile ex Schult. & P. & Ch & ME+ SA-SI + IR-TR \\
\hline & Salsola volkensii Schweinf. \& Asch. & P. & Ch & COSM \\
\hline & Suaeda pruinosa Lange & P. & Ch & $\mathbf{M E}+\mathbf{S A}$ \\
\hline Cistaceae & Helianthemum lippii (L.) Dum. Cours. & P. & Ch & SA-SI + S-Z \\
\hline
\end{tabular}


Ahmed K. Osman et al.

\begin{tabular}{|c|c|c|c|c|}
\hline & Helianthemum vesicarium Boiss. & P. & Ch & SA \\
\hline Cleomaceae & Cleome amblyocarpa Barratte \& Murb. & A. & Th & SA-SI + S-Z \\
\hline \multirow[t]{44}{*}{ Compositae } & Anthemis arvensis $\mathrm{L}$. & A. & Th & SA \\
\hline & Anthemis cotula $\mathrm{L}$. & A. & Th & SA \\
\hline & Anthemis deserti Boiss. & A. & Th & $\mathbf{M E}+\mathbf{S A}$ \\
\hline & Anthemis melampodina Delile. & A. & Th & $\mathbf{M E}+\mathbf{S A}$ \\
\hline & Anthemis pseudocotula Boiss. & A. & Th & $\mathbf{M E}+\mathbf{S A}$ \\
\hline & Anthemis scrobicularis Yavin. & A. & Th & ME+ SA-SI + IR-TR \\
\hline & Artemisia judaica $\mathbf{L}$. & P. & Ch & SA \\
\hline & Artemisia monosperma Delile. & P. & Ch & $\mathbf{M E}+\mathbf{S A}$ \\
\hline & Artemisia scoparia Waldst. \& Kit. & P. & Ch & IR-TR + EU-SI \\
\hline & $\begin{array}{l}\text { Atractylis carduus (Forssk.) } \\
\begin{array}{l}\text { angustifolia } \text { Täckh. \& } \\
\text { \&oulos. }\end{array}\end{array}$ & P. & Th & ME \\
\hline & Calendula arvensis $\mathrm{L}$. & A. & Th & ME+ SA-SI + IR-TR \\
\hline & Calendula tripterocarpa Rupr. & A. & Th & PAN \\
\hline & Carthamus nitidus Boiss. & A. & Th & SA + IR-TR \\
\hline & Carthamus oxyacantha M. Bieb. & A. & Th & ME + IR-TR \\
\hline & Centaurea pseudosinaica Czerp. & A. & Th & IR-TR \\
\hline & Centaurea sinaica DC. & A. & Th & IR-TR+ EU-SI \\
\hline & Chamaemelum mixtum (L.) All. & A. & Th & $\mathbf{M E}+\mathbf{S A}$ \\
\hline & Cotula anthemoides $\mathrm{L}$. & A. & Th & SA \\
\hline & Cotula cinerea Delile. & A. & Th & SA-SI \\
\hline & Crepis nigricans Viv. & A. & Th & SA \\
\hline & Filago desertorum Pomel & A. & Th & SA-SI + IR-TR \\
\hline & Garhadiolus angulosus Jaub. \& Spach. & A. & Th & ME + IR-TR \\
\hline & $\begin{array}{llll}\text { Glebionis coronaria } & \text { (L.) } & \text { Tzvelv. } & \text { (= } \\
\text { Chrysanthemum coronarium } & \text { L.) }\end{array}$ & A. & $\mathbf{H}$ & ME + SA-SI \\
\hline & Gymnarrhena micrantha Desf. & A. & Th & ME + SA-SI \\
\hline & Helichrysum conglobatum (Viv.) Steud. & P. & Th & ME \\
\hline & $\begin{array}{l}\text { Homognaphalium pulvinatum (Delile.) Fayed \& } \\
\text { Zareh. }\end{array}$ & A. & Th & SA-SI+ IR-TR \\
\hline & $\begin{array}{l}\text { Ifloga spicata (Forssk.) Sch. Bip. subsp. albescens } \\
\text { Chrtek. }\end{array}$ & A. & Th & ME + SA-SI \\
\hline & Koelpinia linearis Pall. & A. & Th & ME + SA + IR-TR \\
\hline & Lactuca serriola $\mathrm{L}$. & A./Bi. & Th & IR-TR \\
\hline & Lasiopogon muscoides (Desf.) DC. & A. & Th & ME+SA-SI \\
\hline & Launaea capitata (Spreng.) Dandy & A. & Th & ME+SA-SI \\
\hline & $\begin{array}{l}\text { Launaea fragilis (Asso) Pau subsp. fragilis }(=L . \\
\text { tenuiloba (Boiss.) Kuntze ) }\end{array}$ & A. & Th & $\mathbf{M E}+\mathbf{S A}-\mathbf{S I}$ \\
\hline & $\begin{array}{l}\text { Launaea mucronata (Forssk.) Muschl. subsp. } \\
\text { mucronata }\end{array}$ & s-P. & Th & SA-SI + IR-TR \\
\hline & Launaea nudicaulis (L.) Hook.f. & P. & Th & SA-SI + IR-TR + S-Z \\
\hline & Leontodon hispidulus (Delile.) Boiss. & A. & Th & ME + SA-SI \\
\hline & Leontodon laciniatus (Bertol.) Widder. & A. & Th & ME + SA-SI \\
\hline & Matricaria aurea (Loefl.) Sch. Bip. & A. & Th & SA-SI \\
\hline & $\begin{array}{l}\text { Nauplius graveolens (Forssk.) Wiklund. } \quad(= \\
\text { Asteriscus graveolens (Forssk.) Less.) }\end{array}$ & $\mathbf{P .}$ & Ch & ME + SA-SI \\
\hline & Picris altissima Delile. & A. & Th & $\mathrm{ME}+\mathrm{SA}$ \\
\hline & Picris asplenioides $\mathbf{L}$. & A. & Th & ME + IR-TR \\
\hline & Picris cyanocarpa Boiss. & A. & Th & SA \\
\hline & $\begin{array}{l}\text { Pseudognaphalium luteoalbum (L.) Hilliard \& B. } \\
\text { L. Burtt }\end{array}$ & A. & Th & ME + SA + IR-TR \\
\hline & Reichardia tingitana (L.) Roth & P. & $\mathbf{C r}$ & ME+ SA-SI + IR-TR \\
\hline & Senecio belbeysius Delile. & A. & Th & ME+ IR-TR + EU-SI \\
\hline
\end{tabular}




\begin{tabular}{|c|c|c|c|c|}
\hline & $\begin{array}{l}\text { Senecio glaucus L. subsp. coronopifolius (Maire) } \\
\text { C. Alexander (= S. desfontainei Druce) }\end{array}$ & A. & Ch & SA-SI + IR-TR \\
\hline & Sonchus oleraceus $\mathbf{L}$. & A. & Th & COSM \\
\hline & Sonchus tenerrimus $\mathrm{L}$. & A. & Th & COSM \\
\hline & Urospermum picroides (L.) F.W. Schmidt & A. & Th & ME + IR-TR \\
\hline \multirow[t]{2}{*}{ Convolvulaceae } & Convolvulus arvensis $\mathrm{L}$. & P. & $\mathbf{H}$ & PAL \\
\hline & Cuscuta campestris Yunck. & P. & $\mathbf{P}$ & $\mathbf{S A - S I}+\mathbf{S - Z}$ \\
\hline \multirow[t]{17}{*}{ Cruciferae } & Arabidopsis kneuckeri (Bornm.) O. E. Schulz & A. & Th & SA-SI \\
\hline & Carrichtera annua (L.) DC. & A. & Th & ME + SA-SI \\
\hline & Coronopus didymus (L.) Sm. & A./Bi. & Th & SA \\
\hline & Diplotaxis acris (Forssk.) Boiss. & A. & Th & ME + IR-TR \\
\hline & Enarthrocarpus strangulatus Boiss. & A. & Th & SA-SI \\
\hline & Eruca sativa Mill. & A. & Th & ME + SA+ IR-TR + EU- \\
\hline & Erucaria crassifolia (Forssk.) Delile & A. & Th & ME + SA-SI \\
\hline & Erucaria hispanica (L.) Druce & A. & Th & ME + SA-SI \\
\hline & Farsetia aegyptia Turra & P. & Ch & SA-SI +S-Z \\
\hline & Farsetia stylosa $\mathbf{R}$. Br. & A./s-P. & Th & SA-SI \\
\hline & Horwoodia dicksoniae Turril & A. & Th & SA-SI \\
\hline & Matthiola arabica Boiss. & A. & Th & SA \\
\hline & Matthiola longipetala (Vent.) DC. & A. & Th & ME + IR-TR \\
\hline & Savignya praviflora (Delile) Webb & A. & Th & SA-SI + IR-TR \\
\hline & Schimpera arabica Hochst. \& Steud. ex Endl. & A. & Th & SA-SI \\
\hline & Sisymbrium irio $\mathbf{L}$. & A. & Th & $\begin{array}{c}\text { ME + SA-SI + IR-TR + } \\
\text { EU-SI }\end{array}$ \\
\hline & Zilla spinosa (L.) Prantl subsp. spinosa & $\mathbf{P .}$ & Ch & $\begin{array}{c}\text { ME + SA-SI + IR-TR + } \\
\text { EU-SI }\end{array}$ \\
\hline Cucurbitaceae & Citrullus colocynthis (L.) Schrad. & P. & $\mathbf{H}$ & ME+SA-SI + IR-TR+ S-Z \\
\hline \multirow[t]{3}{*}{ Euphorbiaceae } & Euphorbia peplus $\mathrm{L}$. & A. & Th & COSM \\
\hline & Euphorbia prostrata Aiton & A. & Th & ME + SA-SI + IR-TR \\
\hline & Euphorbia serpens Kunth. & A. & Th & SA-SI + IR-TR \\
\hline Fumariaceae & Hypecoum pendulum $\mathrm{L}$. & A. & Th & ME + IR-TR \\
\hline Geraniaceae & $\begin{array}{l}\text { Erodium crassifolium L'Hér. }(=E . \text { hirtum } \\
\text { (Forssk.) Willd.). }\end{array}$ & P. & Th & SA-SI \\
\hline \multirow[t]{17}{*}{ Gramineae } & Agropyron cristatum (L.) Gaertn. & P. & $\mathbf{H}$ & IR-TR \\
\hline & Bromus scoparius $\mathbf{L}$. & A. & Th & ME + SA-SI + IR-TR \\
\hline & Bromus tectorum $\mathrm{L}$. & A. & Th & COSM \\
\hline & Cutandia memphitica (Spreng.) Benth. & A. & Th & ME + IR-TR \\
\hline & Cynodon dactylon (L.) Pers. & P. & $\mathbf{G}$ & PAN \\
\hline & $\begin{array}{l}\text { Enneapogon lophotrichus Chiov. ex H. Scholz \& } \\
\text { P. Köng }\end{array}$ & A. & Th & IR-TR \\
\hline & Eragrostis aegyptiaca (Willd) Delile. & A. & Th & $\mathbf{S - Z}$ \\
\hline & Eremopyrum bonaepartis (Spreng.) Nevski & A. & Th & IR-TR \\
\hline & Eremopyrum distans (K. Koch) Nevski & A. & Th & IR-TR \\
\hline & $\begin{array}{l}\text { Hordeum murinum L. subsp. glaucum (Steud.) } \\
\text { Tzvelev }\end{array}$ & A. & Th & ME + IR-TR \\
\hline & $\begin{array}{l}\text { Hordeum murinum L. subsp. leporinum (Link.) } \\
\text { Arcang. }\end{array}$ & A. & Th & ME + IR-TR \\
\hline & Lamarckia aurea (L.) Moench & A. & Th & ME + IR-TR + S-Z \\
\hline & Lolium multiflorum Lam. & A. & Th & ME+ IR-TR + EU-SI \\
\hline & Lolium perenne $\mathrm{L}$. & A. & Th & COSM \\
\hline & Lolium rigidum Gaudin & A. & Th & ME + IR -TR \\
\hline & Parapholis incurva (L.) C.E. Hubb & A. & Th & ME+ IR-TR + EU-SI \\
\hline & Phalaris paradoxa $\mathrm{L}$. & A. & Th & ME + IR-TR \\
\hline
\end{tabular}


Ahmed K. Osman et al.

\begin{tabular}{|c|c|c|c|c|}
\hline & Poa annua $\mathrm{L}$. & A./s-P. & Th & ME+ IR-TR + EU-SI \\
\hline & Polypogon maritimus Willd. & A. & $\mathbf{G}$ & COSM \\
\hline & Polypogon monspeliensis (L.) Desf. & A. & Th & ME + SA-SI + IR-TR \\
\hline & Rostraria pumila (Desf.) Tzvelev. & A. & Th & ME + SA-SI \\
\hline & Schismus arabicus Nees. & A. & Th & ME + SA + IR-TR \\
\hline & Schismus barbatus (L.) Thell. & A. & Th & ME + SA-SI + IR-TR \\
\hline & Setaria pumila (Poir.) Roem. \& Schutt. & A. & Th & ME + IR-TR + S-Z \\
\hline & Stipagrostis ciliata (Desf.) De Winter & P. & $\mathbf{H}$ & $\mathrm{SA}+\mathrm{IR}-\mathrm{TR}+\mathrm{SU}$ \\
\hline & Triticum aestivum $\mathrm{L}$. & A. & Th & SA + IR-TR + SU \\
\hline \multirow[t]{6}{*}{ Labiatae } & Phlomis brachyodon (Boiss.) Zoh. & P. & $\mathbf{H}$ & IR-TR \\
\hline & Salvia aegyptiaca $\mathbf{L}$. & P. & Ch & $\mathbf{S A - S I}+\mathbf{S}-\mathbf{Z}$ \\
\hline & Salvia lanigera Poir. & P. & Ch & ME + SA-SI \\
\hline & Salvia spinosa $\mathrm{L}$. & P. & $\mathbf{H}$ & ME + IR-TR \\
\hline & Teucrium oliverianum Ging. ex. Benth. & P. & Ch & COSM \\
\hline & Teucrium polium $\mathrm{L}$. & P. & Ch & ME + IR-TR \\
\hline \multirow[t]{22}{*}{ Leguminosae } & Alhagi graecorum Boiss. & P. & Ch & $\mathrm{ME}+\mathrm{SA}+\mathrm{IR}-\mathrm{TR}+\mathrm{SU}$ \\
\hline & Astragalus bombycinus Boiss. & A. & $\mathbf{H}$ & SA-SI+ IR-TR \\
\hline & Astragalus corrugatus Bertol. subsp. corrugatus & A. & Th & IR-TR \\
\hline & Astragalus hauarensis Boiss. & A. & $\mathbf{H}$ & IR-TR \\
\hline & Astragalus schimperi Boiss. var. subsessilis & A. & Th & ME \\
\hline & Astragalus sieberi DC. & P. & Ch & SA + IR-TR \\
\hline & Astragalus spinosus (Forssk.) Muschl. & P. & Ch & SA-SI + IR-TR \\
\hline & Astragalus tribuloides Delile var. tribuloides & A. & Th & SA-SI + IR-TR \\
\hline & Hippocrepis areolata Desv. & A. & Th & $\mathbf{M E}+\mathbf{S}-\mathbf{Z}$ \\
\hline & Hippocrepis cyclocarpa Murb. & A. & Th & ME \\
\hline & Hippocrepis multisiliquosa $\mathrm{L}$. & A. & Th & IR-TR \\
\hline & $\begin{array}{l}\text { Medicago laciniata (L.) Mill. var. brachyacantha } \\
\text { Boiss. }\end{array}$ & A. & Th & SA-SI \\
\hline & Medicago laciniata (L.) Mill. var. laciniata & A. & Th & SA-SI \\
\hline & Medicago monspeliaca (L.) Trautv. & A. & Th & ME + IR-TR \\
\hline & Medicago polymorpha $\mathrm{L}$. & A. & Th & ME+ IR-TR + EU-SI \\
\hline & Melilotus albus Medik. & A. & Th & ME + SA + IR-TR \\
\hline & Melilotus indicus (L.) All. & A. & Th & PAL \\
\hline & Onobrychis ptolemaica (Delile.) DC. & P. & $\mathbf{H}$ & IR-TR \\
\hline & $\begin{array}{l}\text { Tephrosia purpurea (L.) Pers. subsp. Leptostachya } \\
\text { (DC.) Brummitt, Bol. }\end{array}$ & $\mathbf{P .}$ & Ch & SA-SI + S-Z \\
\hline & Trigonella hamosa $\mathrm{L}$ & A. & Th & ME + SA-SI \\
\hline & Trigonella laciniata $\mathrm{L}$. & A. & Th & ME + SA-SI + IR-TR \\
\hline & Trigonella stellata Forssk. & A. & Th & SA-SI + IR-TR \\
\hline Malvaceae & Malva parviflora $\mathrm{L}$. & A. & Th & PAN \\
\hline Orobanchaceae & Cistanche phelypaea (L.) Cout. & P. & $\mathbf{P}$ & ME+SA-SI + IR-TR+ S-Z \\
\hline \multirow[t]{7}{*}{ Plantaginaceae } & $\begin{array}{l}\text { Plantago amplexicaulis Cav. subsp. Bauphula } \\
\text { (Edgew.) Rech. f. }\end{array}$ & A. & Th & SA-SI + IR-TR \\
\hline & Plantago ciliata Desf. & A. & Th & ME + SA-SI + IR-TR \\
\hline & Plantago crassifolia Forssk. & A. & $\mathbf{H}$ & ME \\
\hline & Plantago lagopus $\mathbf{L}$. & A. & Th & ME + IR-TR \\
\hline & Plantago lanceolata $\mathbf{L}$. & A. & Th & ME + SA-SI+ IR-TR \\
\hline & Plantago ovata Forssk. & A. & Th & SA + IR-TR \\
\hline & Plantago psammophila Agnew \& Chalibi-Ka, bi. & A. & Th & SA-SI + IR-TR \\
\hline \multirow[t]{3}{*}{ Polygonaceae } & Emex spinosa (L.) Campd. & A. & Th & PAN \\
\hline & Polygonum equisetiforme $\mathrm{Sm}$. & A. & Ch & M + IR-TR \\
\hline & Rumex vesicarius $\mathrm{L}$. & P. & Th & $\mathrm{ME}+\mathrm{SA}-\mathrm{SI}+\mathrm{S}-\mathrm{Z}$ \\
\hline Portulacaceae & Portulaca oleracea $\mathrm{L}$. & A. & Th & ME + SA-SI \\
\hline Primulaceae & Anagallis arvensis $\mathbf{L}$. var. arvensis & A. & Th & ME+ IR-TR + EU-SI \\
\hline
\end{tabular}




\begin{tabular}{|c|c|c|c|c|}
\hline Resedaceae & $\begin{array}{l}\text { Oligomeris linifolia (Vahl ex Hornem.) J. F. } \\
\text { Macbr. ( = Reseda linifolia Vahl ex Hornem.) }\end{array}$ & A. & Th & $\mathrm{ME}+\mathrm{SA}+\mathrm{S}-\mathrm{Z}$ \\
\hline & Reseda muricata C. Presl. & A. & Th & SA-SI + IR-TR \\
\hline Scrophulariaceae & Veronica polita Fr. (= V. didyma sensu auct) & A. & Th & M + IR-TR \\
\hline \multirow[t]{2}{*}{ Solanaceae } & Hyoscyamus muticus $\mathrm{L}$. & P. & Ch & SA-SI + IR-TR \\
\hline & Solanum nigrum $\mathbf{L}$. & P. & Ch & COSM \\
\hline \multirow[t]{8}{*}{ Umbelliferae } & Ammi majus L. & A. & Th & ME \\
\hline & Anisosciadium isosciadium Bornm. & A. & Th & SA + IR-TR \\
\hline & Anisosciadium lanatum Boiss. & A. & Th & SA + IR-TR \\
\hline & Deverra tortuosa (Desf.) DC. & P. & $\mathbf{C h}$ & SA-SI \\
\hline & Ducrosia anethifolia (DC.) Boiss. & P. & Th & IR-TR \\
\hline & Ferula ovina (Boiss.) Boiss. & P. & $\mathbf{C h}$ & IR-TR \\
\hline & $\begin{array}{l}\text { Petroselinum crispum (Mill.) A. W. Hill. }=P \text {. } \\
\text { Sativum (L.) P. Hoffm. }\end{array}$ & Bi. & Th & PAL \\
\hline & Tordylium aegyptiacum (L.) Poir. & A. & Th & $\mathbf{M E}+\mathbf{S A}$ \\
\hline Urticaceae & Forsskaolea tenacissima $\mathrm{L}$. & A. & $\mathbf{H}$ & SA-SI + S-Z \\
\hline \multirow[t]{6}{*}{ Zygophyllaceae } & Fagonia bruguieri DC. & P. & $\mathbf{H}$ & SA-SI + IR-TR \\
\hline & Fagonia glutinosa Delile & P. & $\mathbf{H}$ & SA-SI \\
\hline & Peganum harmala $\mathbf{L}$. & P. & $\mathbf{H}$ & ME + SA-SI + IR-TR \\
\hline & Tribulus macropterus Boiss. & A. & Ch & SA-SI + IR-TR \\
\hline & Tribulus megistopterus Kralik. & A. & $\mathbf{C h}$ & SA-SI + IR-TR \\
\hline & Zygophyllum simplex $\mathrm{L}$. & A. & Th & SA-SI + S-Z \\
\hline
\end{tabular}


Table (2). Summary table showing the total number of families, genera and species, growth types and life forms of collected plants.

\begin{tabular}{|c|c|c|c|c|c|c|c|c|}
\hline \multicolumn{3}{|c|}{ Total number of } & \multicolumn{3}{|c|}{ Growth type } & \multicolumn{3}{|c|}{ Life forms } \\
\hline Families & Genera & Species & Type & $\begin{array}{c}\text { Number } \\
\text { of species }\end{array}$ & $\begin{array}{c}\text { Percentage } \\
(\%)\end{array}$ & Form & $\begin{array}{c}\text { Number } \\
\text { of species }\end{array}$ & $\begin{array}{c}\text { Percentage } \\
(\%)\end{array}$ \\
\hline \multirow{9}{*}{30} & \multirow{9}{*}{129} & \multirow{9}{*}{194} & Annual & 135 & 69.59 & $\mathbf{H}$ & 16 & 8.24 \\
\hline & & & Perennial & 52 & 26.80 & Ch & 33 & 17.01 \\
\hline & & & Biennial & 2 & $\mathbf{1 . 0 3}$ & $\mathbf{P h}$ & 1 & 0.52 \\
\hline & & & \multirow{2}{*}{$\begin{array}{l}\text { Annual or } \\
\text { short- } \\
\text { Perennial }\end{array}$} & \multirow[t]{2}{*}{2} & \multirow[t]{2}{*}{1.03} & Th & 139 & 71.65 \\
\hline & & & & & & $\mathbf{P}$ & 2 & 1.03 \\
\hline & & & \multirow{2}{*}{$\begin{array}{c}\text { Annual or } \\
\text { Biennial }\end{array}$} & \multirow[t]{2}{*}{2} & \multirow[t]{2}{*}{1.03} & $\mathbf{G}$ & 2 & 1.03 \\
\hline & & & & & & $\mathrm{Cr}$ & 1 & 0.52 \\
\hline & & & $\begin{array}{c}\text { short- } \\
\text { Perennial }\end{array}$ & 1 & 0.52 & & & \\
\hline & & & $\begin{array}{c}\text { Total } \\
\text { Number }\end{array}$ & 194 & $100 \%$ & $\begin{array}{c}\text { Total } \\
\text { Number }\end{array}$ & 194 & $100 \%$ \\
\hline
\end{tabular}


Table (3). The number of recorded species belonging to the main floristic categories and their relevant percent (\%) abbreviations.

\begin{tabular}{|c|c|c|}
\hline Phytochoria & Number of species & Percentage $(\%)$ \\
\hline \multicolumn{3}{|l|}{ Monoregional } \\
\hline ME & 06 & 3.09 \\
\hline SA-SI & 13 & 6.70 \\
\hline IR-TR & 15 & 7.73 \\
\hline SA & 10 & 5.16 \\
\hline S-Z & 02 & 1.03 \\
\hline Total & 46 & 23.71 \\
\hline \multicolumn{3}{|l|}{ Biregionals } \\
\hline SA-SI + S-Z & 16 & 8.25 \\
\hline $\mathrm{SA}+\mathrm{S}-\mathrm{Z}$ & 01 & 0.52 \\
\hline ME + SA-SI & 19 & 9.79 \\
\hline ME + IR-TR & 19 & 9.79 \\
\hline SA + IR-TR & 06 & 3.09 \\
\hline $\mathbf{M E}+\mathbf{S A}$ & 08 & 4.12 \\
\hline IR-TR + EU-SI & 02 & 1.03 \\
\hline SA-SI + IR-TR & 17 & 8.77 \\
\hline $\mathrm{ME}+\mathrm{S}-\mathrm{Z}$ & 01 & 0.52 \\
\hline Total & 89 & 45.88 \\
\hline \multicolumn{3}{|l|}{ Pleuriregionals } \\
\hline ME + SA-SI + IR-TR & 14 & 7.20 \\
\hline ME + SA + IR-TR & 06 & 3.09 \\
\hline ME+ IR-TR + EU-SI & 06 & 3.09 \\
\hline ME + IR-TR + S-Z & 02 & 1.03 \\
\hline ME + SA-SI + IR-TR + EU-SI & 02 & 1.03 \\
\hline ME+SA-SI + IR-TR+ S-Z & 02 & 1.03 \\
\hline ME + SA+ IR-TR + EU-SI & 01 & 0.52 \\
\hline $\mathrm{ME}+\mathrm{SA}+\mathrm{IR}-\mathrm{TR}+\mathrm{SU}$ & 01 & 0.52 \\
\hline $\mathrm{ME}+\mathrm{SA}+\mathrm{S}-\mathrm{Z}$ & 01 & 0.52 \\
\hline ME + SA-SI + S-Z & 01 & 0.52 \\
\hline SA-SI + IR-TR + S-Z & 01 & 0.52 \\
\hline SA + IR-TR + SU & 02 & 1.03 \\
\hline Total & 39 & 20.10 \\
\hline$\overline{c \text { Cosm }}$ & 12 & 6.19 \\
\hline Pal & 04 & 2.06 \\
\hline Pan & 04 & 2.06 \\
\hline Total & 20 & 10.31 \\
\hline
\end{tabular}

